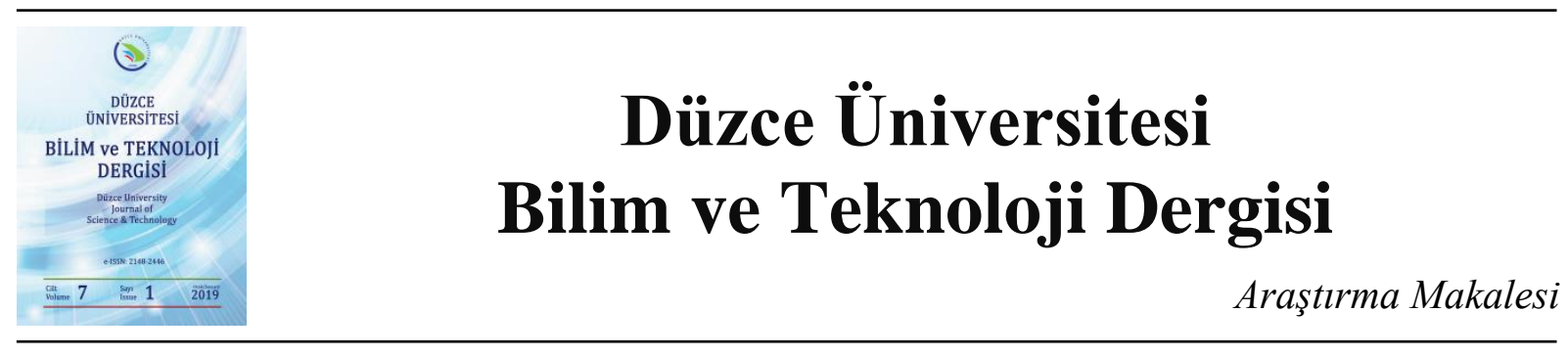

\title{
Fosil Yakıtlı Bir Enerji Santrali Prosesinin Modellenmesi ve Ana Buhar Basıncı Parametresinin Kestirim Başarımı Analizi
}

\author{
Yasin TUNÇKAYA ${ }^{a}{ }^{*}$ \\ ${ }^{a}$ Elektronik ve Haberleşme Mühendisi, Honeywell Teknoloji A.Ş, İstanbul, TÜRKIYE \\ * Sorumlu yazarin e-posta adresi : yasintun@yahoo.com
}

\begin{abstract}
ÖZET
Günümüzde sıkça kullanılmakta olan fosil yakıtlı enerji santralleri, sanayi ve üretim sektörünün vazgeçilmezi olan elektrik enerjisi ve buhar ihtiyacını gidermesi nedeniyle kritik bir öneme sahip olmakla birlikte, çevreye olumsuz etkileri nedeniyle değişik tartışmalara sebebiyet vermektedir. Bu çalı̧mada, Türkiye' de kurulu bulunan 135 MW' lık enerji üretim kapasitesine sahip fosil yakıtlı bir enerji santralinin işletme ve proses analizi yapılmış ve kritik operasyon parametrelerinden 19 adeti seçilerek güncel yapay zeka yöntemlerinden olan Yapay Sinir Ağları (YSA) ile santralin modellemesi gerçekleştirilmiştir. Santralden elde edilen geçmiş döneme ait her bir parametreye ait 1440 adet proses verisi, veri madenciliği teknikleri ile harmanlanmış, işletmenin en önemli çıkış parametrelerinden biri olan ana buhar basıncı değerinin çeşitli yaklaşım ve denemelerle tahmin edildiği bir kestirim çalışması sunulmuştur. Çıkan sonuçlar, istatistiksel kestirim yöntemlerinden biri olan ve literatürde sıkça kullanılan Çoklu Doğrusal Regresyon (ÇDR) yöntemi ile karşılaştırılmıştır. Kök ortalama karesel hata yaklaşımı ve determinasyon katsayısı ile başarım takibi yapılan bu kestirim çalışmasında, sırasıyla, YSA modelinden elde edilen 0,994 ve 0,0039 değerlerinin, ÇDR modelinden elde edilen 0,970 ve 0,0172 değerlerine göre daha iyi başarım gösterdiği bulunmuştur. Ayrıca literatürdeki benzer bir çalışma ile karşılaştırma yapılarak, çalışmada seçilen giriş değiş̧kenleri ve YSA model parametrelerinin çok başarılı olduğu gösterilmiştir.
\end{abstract}

Anahtar Kelimeler: Enerji Santralleri, Yapay Sinir Ağları, Çoklu Doğrusal Regresyon, Kestirim

\section{Modeling of a Fossil Fuel-Fired Power Plant Process and Analysis of Prediction Success of Main Steam Pressure Parameter}

\begin{abstract}
Although fossil fuel fired power plants, which are frequently used nowadays, have critical importance due to electricty and steam production for industry and manufacturing works, they are under criticism due to their negative impacts on the environment. In this study, an operation and process analysis of a $135 \mathrm{MW}$ fossil fuel fired power plant located at Turkey is carried out and the plant is modeled with Artificial Neural Networks (ANN), which is one of contemporary artificial intelligence method, selecting 19 critical input parameters. Previous process values of the parameters are obtained from the power plant, each contains 1440 process data, blended with data mining techniques, and main steam pressure parameter, which is one of the most important output parameter of the plant, is estimated by various approaches and experiments. The results are compared
\end{abstract}

Geliş: 24 / 09/ 2018, Düzeltme: 12 / 12 / 2018, Kabul: 18 / 12 / 2018 
with the Multiple Linear Regression (MLR) approach, one of the frequently used statistical forecasting method in literature.

In this estimation study, root mean square error and determination coefficient terms are used for comparison, and the outputs are founded as 0.0994 and 0.0039 for ANN model, 0.970 and 0.0172 for MLR model respectively. Additionally, a comparison benchmarking is made with a similar study in literature, and it is shown that the parameters of ANN model and selection of input variables are found very successful.

Keywords: Artificial Neural Networks, Multiple Linear Regression, Power Plants, Prediction 